\title{
Future potential distribution of the emerging amphibian chytrid fungus under anthropogenic climate change
}

\author{
Dennis Rödder ${ }^{1,2}$, Jos Kielgast ${ }^{3, *}$, Stefan Lötters ${ }^{2}$ \\ ${ }^{1}$ Zoologisches Forschungsmuseum Alexander Koenig, Adenauerallee 160, 53113 Bonn, Germany \\ ${ }^{2}$ Department of Biogeography, Trier University, Am Wissenschaftspark 25-27, 54296 Trier, Germany \\ ${ }^{3}$ Natural History Museum of Denmark, Zoological Museum, Universitetsparken 15, 2100 Copenhagen, Denmark
}

\begin{abstract}
Anthropogenic climate change poses a major threat to global biodiversity with a potential to alter biological interactions at all spatial scales. Amphibians are the most threatened vertebrates and have been subject to increasing conservation attention over the past decade. A particular concern is the pandemic emergence of the parasitic chytrid fungus Batrachochytrium dendrobatidis, which has been identified as the cause of extremely rapid large-scale declines and species extinctions. Experimental and observational studies have demonstrated that the host-pathogen system is strongly influenced by climatic parameters and thereby potentially affected by climate change. Herein we project a species distribution model of the pathogen onto future climatic scenarios generated by the IPCC to examine their potential implications on the pandemic. Results suggest that predicted anthropogenic climate change may reduce the geographic range of $B$. dendrobatidis and its potential influence on amphibian biodiversity.
\end{abstract}

KEY WORDS: Amphibia - Anthropogenic future climate change - Batrachochytrium dendrobatidis . Bioclimate $\cdot$ Chytridiomycosis $\cdot$ Global warming $\cdot$ Maxent $\cdot$ Species distribution model

\section{INTRODUCTION}

Increasing anthropogenic activity is causing environmental change and severely degrading global biodiversity. It has been suggested that we are currently witnessing the onset of a sixth mass extinction (Wake \& Vredenburg 2008). Amphibians are among the most dramatically affected organisms, with about one-third of the approximately 6500 described species threatened with extinction under the IUCN Red List of Threatened Species (Gascon et al. 2007, Stuart et al. 2008). The emerging infectious disease chytridiomycosis, caused by the chytrid fungus Batrachochytrium dendrobatidis $(B d)$, has been given particular attention (Mendelson et al. 2006, Lips et al. 2008). The pandemic spread of this pathogen (from a yet unknown source) is suggested to be the proximate cause of rapid decline and extinction of amphib- ian species across the globe (Skerratt et al. 2007, Stuart et al. 2008). It has been shown that susceptibility to $B d$ is widely distributed among the Amphibia, both geographically and taxonomically (Bielby et al. 2008). Although some evidence is controversial (Rohr et al. 2008), there is general consensus that the hostpathogen system is strongly influenced by climatic parameters (Woodhams \& Alford 2005, Pounds et al. 2006, Rachowicz et al. 2006, Alford et al. 2007, Bosch et al. 2007, Kriger \& Hero 2007, Kriger et al. 2007, Andre et al. 2008, Laurance 2008, Lips et al. 2008, Pounds \& Coloma 2008, Rödder et al. 2008, Kielgast et al. 2009). Furthermore, $B d$ 's thermal tolerance and growth rate, determined in laboratory studies (Piotrowski et al. 2004), are well reflected in prevalence and intensity of $B d$ infection in the wild (Kriger \& Hero 2007, Kriger et al. 2007, Rödder et al. 2008, Kielgast et al. 2009). 
Species distribution models (SDMs) are a widely used tool in contemporary data-driven conservation biology (Araújo et al. 2004, Kremen et al. 2008) and can be successfully applied to predict potential distributions of diseases (e.g. Levine et al. 2007, Lafferty 2009). In SDMs, predictions of a species' potential distribution can be made using GIS technology and environmental parameters such as climate, characterizing the species' niche. The SDM result is a map indicating the environmental (e.g. climatic) suitability at given sites for the target species. In order to uncover $B d$ 's invasive geographic potential including uninfected regions, some authors have already successfully applied SDMs on $B d$ using climatic predictors (Ron 2005, Lötters et al. 2008, Puschendorf et al. 2009, Rödder et al. 2009a). However, predictions on future scenarios for the panzootic including anthropogenic climate change are lacking. We suggest that such an approach is intriguing and relevant, as alteration of species distributions related to climate change is expected to happen on a large scale over the next decades (Parmesan 2006). Additionally, the particular impact of future anthropogenic climate change on $B d$ spread and chytridiomycosis epizootics has already been advocated by multiple authors (e.g. Pounds et al. 2006, 2007, Alford et al. 2007, Bosch et al. 2007, Laurance 2008, Pounds \& Coloma 2008). In the present study, we develop an SDM to characterize $B d$ 's climate niche and project it onto currently expected anthropogenic future climate change scenarios.

\section{MATERIALS AND METHODS}

We ran a $B d$ SDM (Fig. 1A) using Maxent 3.3.1 (Phillips et al. 2006, Phillips \& Dudík 2008; www.cs. princeton.edu/ schapire/maxent), in the manner of Rödder et al. (2009a). It was based on 365 globally distributed $B d$ records taken from www.spatialepide miology.net/bd-maps; species records posted on this webpage were compiled from numerous scientific publications (cited on the webpage). $B d$ surveys were not conducted randomly over the world (Fig. 1A), leaving the possibility of a sample selection bias violating SDM assumptions (Phillips 2008). Therefore, 19 bioclim values (Nix 1986, Busby 1991) provided by Worldclim (Hijmans et al. 2005a) records were extracted from $B d$ records and a cluster analysis based on Euclidean distances was performed. Resulting classes were blunted at a threshold of 200 classes, and only one randomly chosen record per class was used for further processing. This method reduces the amount of duplicate information in the feature space and thereby the impact of samples clumped in geographic space (Rödder et al. 2009a). All calculations were performed with XLSTAT 2008 (Addinsoft, www.xlstat.com).
Maxent has been developed within the machine learning community and implements an algorithm for making predictions and inferences from incomplete information. This algorithm estimates geographic distributions of species from environmental conditions as observed from species records and random background data by finding the maximum entropy distribution (Phillips et al. 2006, Phillips \& Dudík 2008). In the present study, the logistic output format was chosen, which produces continuous, linear scaled maps ranging from 0 (unsuitable) to 1 (optimal) showing the potential distribution of the target species. This method allows for more fine-scale distinction of the potential distributions than what can be achieved with similar methods such as GARP (genetic algorithm for rule-set production) models (Phillips et al. 2006). Also, in numerous comparative studies, Maxent has achieved better results than other presence-only methods (Elith et al. 2006, Hernandez et al. 2006). It has been suggested that ensemble model predictions may enhance the reliability and robustness of SDM results (Araújo \& New 2007). Therefore, 100 models were computed and subsequently integrated into a map indicating the average Maxent value per grid cell.

As environmental predictors, 6 bioclimate variables were used: annual mean temperature, maximum temperature of the warmest month, minimum temperature of the coldest month, annual precipitation, precipitation of the wettest month and precipitation of the driest month (Hijmans et al. 2005a, www.worldclim.org). Laboratory studies (Piotrowski et al. 2004, Woodhams et al. 2008), field studies (Kriger \& Hero 2007, Kriger et al. 2007, Rödder et al. 2008, Kielgast et al. 2009) and previous attempts to map $B d$ 's potential distribution at a local scale (Lötters et al. 2008, Puschendorf et al. 2009) have shown that these parameters are physiologically relevant for this pathogen and correlated with $\mathrm{Bd}$ prevalence and infection rates.

Ideally, the area from which random background data is obtained for model building reflects those regions accessible to the target species, since areas with climate conditions not analogous to those represented by background data may lead to uncertainties in model predictions (Phillips 2008). To account for this, background samples were restricted to areas from which $B d$ was detected in the wild. Maxent automatically allows an identification of the degree of uncertainty when projecting models (clamping), which was removed from our $B d$ SDM.

Model validation was performed by using the area under the curve (AUC), referring to the receiver operating characteristic (ROC) curve, a threshold-independent index widely used in ecological modelling (e.g. Manel et al. 2001, Elith et al. 2006). Two tests were performed: (1) the model's ability to distinguish between 


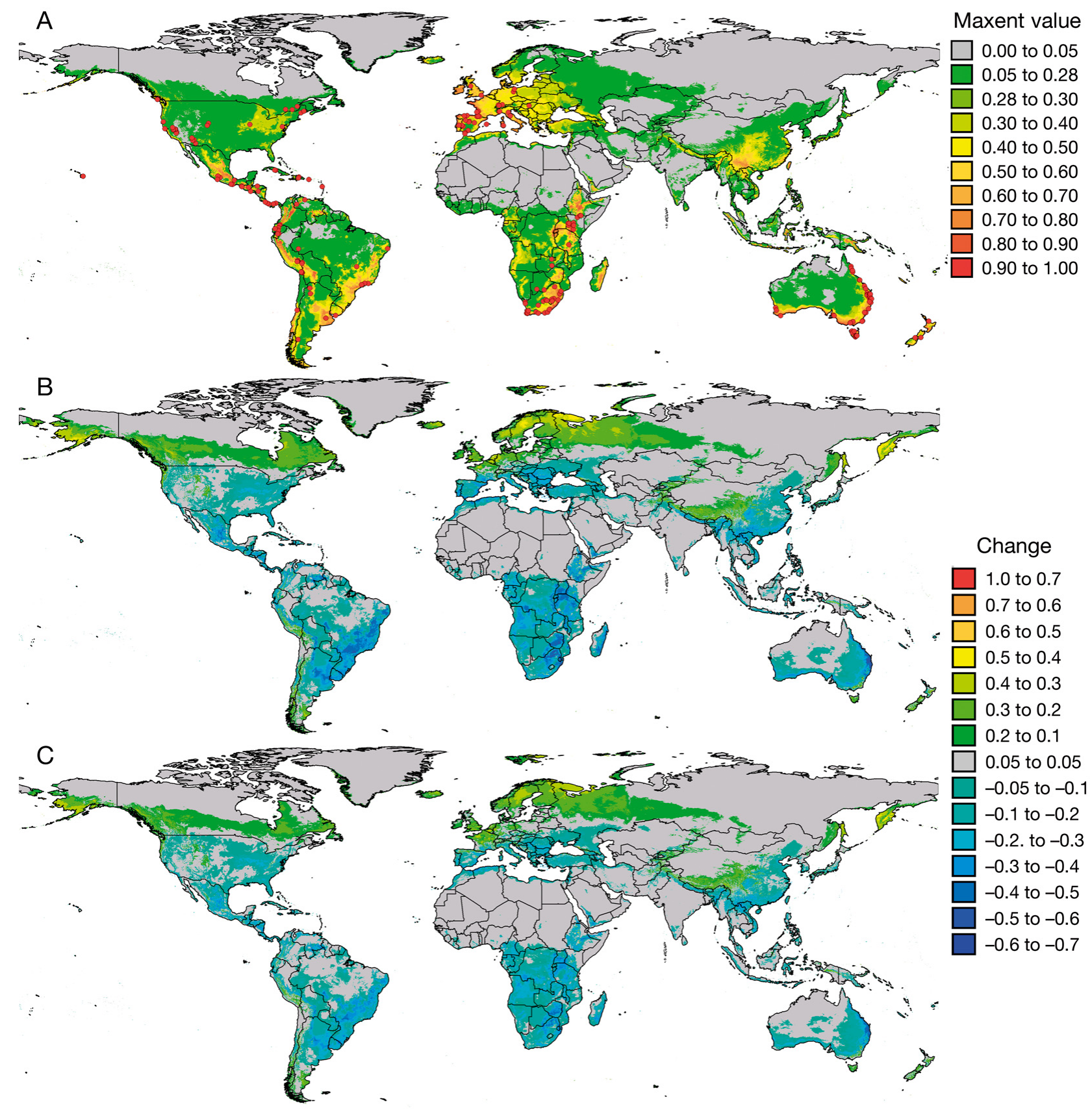

Fig. 1. (A) Potential distribution of Batrachochytrium dendrobatidis (Bd) under current climatic conditions based on a Maxent species distribution model (SDM) and Bd presence localities used for SDM building (red dots), with warmer Maxent colour indicating higher suitability to the fungus. (B) Change in the potential distribution of $B d$ under future climatic scenarios (i.e. the year 2080) relative to current conditions based on mean values per grid cell of the A2a family when projected onto the CCCMA, CSIRO and HADCM3 models. (C) Change computed with the mean predictions of the climate change models assuming B2a conditions (for particular 2080 SDMs each for CCCMA, CSIRO and HADCM3 see Figs. S2 \& S3 in the supplement, available at www.int-res.com/articles/suppl/d092p201_supp.pdf)

$B d$ records and randomly chosen background points (referred to as $\mathrm{AUC}_{\text {training }}$ ) and (2) its ability to predict a subset of records, setting aside $25 \%$ randomly chosen $B d$ records as test points and using the remaining ones as training points (referred to as $\mathrm{AUC}_{\text {test }}$ ). Maxent cal- culates the mean minimum training presence and the mean lowest 10th percentile training presences at each run; values greater than these may be interpreted as reasonable approximation of a species' potential distribution. Nevertheless, the higher a Maxent value the 
better the climatic suitability for the modelled species (Phillips et al. 2006, Phillips \& Dudík 2008). For quantitative comparisons between current-day and future scenarios, we counted the number of SDM grid cells of different Maxent values with DIVA-GIS 5.4 (Hijmans et al. 2005b).

For future projections, we used anthropogenic future climate change scenarios for the year 2080 based the CCCMA, CSIRO and HADCM3 models (Flato et al. 2000, Gordon et al. 2000) and the emissions scenarios reported in the IPCC Special Report on Emissions Scenarios (SRES) (IPCC 2000). A set of different families of emission scenarios was formulated based on future production of greenhouse gases and aerosol precursor emissions by the IPCC, which distinctly address demographic, politico-economic, social and technological developmental aspects of climate change. The SRES families A2a and B2a were used in the present study. Each family described one possible demographic, politico-economic, social and technological future. B2a emphasizes more environmentally conscious, regionalized solutions to economic, social and environmental sustainability. Compared to B2a, scenarios of the A2a family also emphasize regionalized solutions to economic and social development, but it is less environmentally conscious. Data sets were also obtained via WorldClim (www.worldclim.org) and the current-day $B d$ SDM was projected onto these data sets in order to assess the future potential distribution of $B d$.

\section{RESULTS AND DISCUSSION}

The conducted $B d$ model received 'good' to 'excellent' AUC values following previously given definitions (Swets 1988), suggesting a high quality of our $\mathrm{SDM}$ output (mean $\mathrm{AUC}_{\text {training }}=0.937$; mean $\mathrm{AUC}_{\text {test }}=$ 0.910). Analysis of the relative contribution of each variable to the 100 models revealed that annual mean temperature had the highest explanatory power (28.7 to $53.5 \%$, mean $\pm \mathrm{SD}=44.29 \pm 4.79 \%$ ), followed by maximum temperature of the warmest month (13.70 to $36.10 \%$, mean $\pm \mathrm{SD}=23.15 \pm 4.31 \%$ ). Mean contributions of the other variables were below $10 \%$. Modelbased uncertainties in future predictions in terms of standard deviations of Maxent values per grid cell were comparatively low (Fig. S1 in the supplement, available at www.int-res.com/articles/suppl/d092p201_ supp.pdf). The mean minimum training presence was $0.05(0.01$ to $0.18, \mathrm{SD}=0.03)$ and the mean lowest 10 th percentile training presence was 0.28 (0.21 to 0.35 , $\mathrm{SD}=0.03)$.

As pointed out in previous studies aiming to model $B d$ 's potential distribution based on current climate (Ron 2005, Lötters et al. 2008, Puschendorf et al. 2009,
Rödder et al. 2009a), the areas of highest suitability to the pathogen have a patchy distribution (Fig. 1A). In the tropics, $B d$ is largely associated with higher altitudes including the Mexican Meseta, the Andean massif, Pantepui and the Mata Atlantica in the Neotropics, the Cameroon Mountains, Ethiopian highlands and higher portions of the Rift Valley and eastern Madagascar in the Aethiopis, and the Sumatran and New Guinean highlands in the Orientalis. Towards the poles, in the Northern Hemisphere the highest suitability for $B d$ occurs over almost all of western Europe, the southern Himalayan slopes and adjacent areas in China to the east, while in the Southern Hemisphere, large portions of southern South America and southeastern Africa as well as New Zealand and southern and southeastern Australia are most suitable for $B d$. Many of these regions coincide with hotspots of amphibian species richness and endemism expected to be susceptible to $B d$ infection (Bielby et al. 2008, Rödder et al. 2009a).

The projected Maxent SDMs in Fig. 1B,C show the potential distribution of $B d$ as expected for 2080. Since our SDM projections onto the CCCMA, CSIRO and HADCM3 scenarios merely revealed minor differences, only mean values are given in Fig. 1B,C (for particular A2a and B2a SDM maps of each scenario see Figs. S2 \& S3 in the supplement). Both maps are largely similar, identifying the following as the most suitable regions for $B d$ (in terms of highest Maxent values): the Mexican Meseta, the Andean region, western Europe, part of the East African Rift Valley, China's Yunnan Province, part of New Guinea, the southern edges of South America, Africa and Australia, and New Zealand. Large portions of North America, western Europe, southern Asia and the southernmost regions of the Southern Hemisphere are also within the potential distribution of the amphibian chytrid fungus, but at a lower level of suitability. The tropics are least suitable for $B d$, with the exception of highland regions.

Compared to the SDM based on current climate (Fig. 1A), regions suitable for $B d$ in the future largely remain suitable, except for most of the tropical lowlands (e.g. Amazon and Congo River basins). It is noteworthy that climatic suitability for $B d$ in terms of Maxent values per grid cell decreases under anthropogenic future climate change scenarios with the A2a family (i.e. less environmentally conscious) (Fig. 2). This is particularly applicable to tropical and subtropical regions, for example, the Mexican Meseta, the northern Andes, the southeastern coastal region of South America, Africa (southwest and Rift Valley highlands), Madagascar, southern Asia and Australia (Fig. 1B,C).

There are 3 possible alternatives to how species ranges may respond to climate change when niche conservatism is expected: they may (1) increase, (2) 


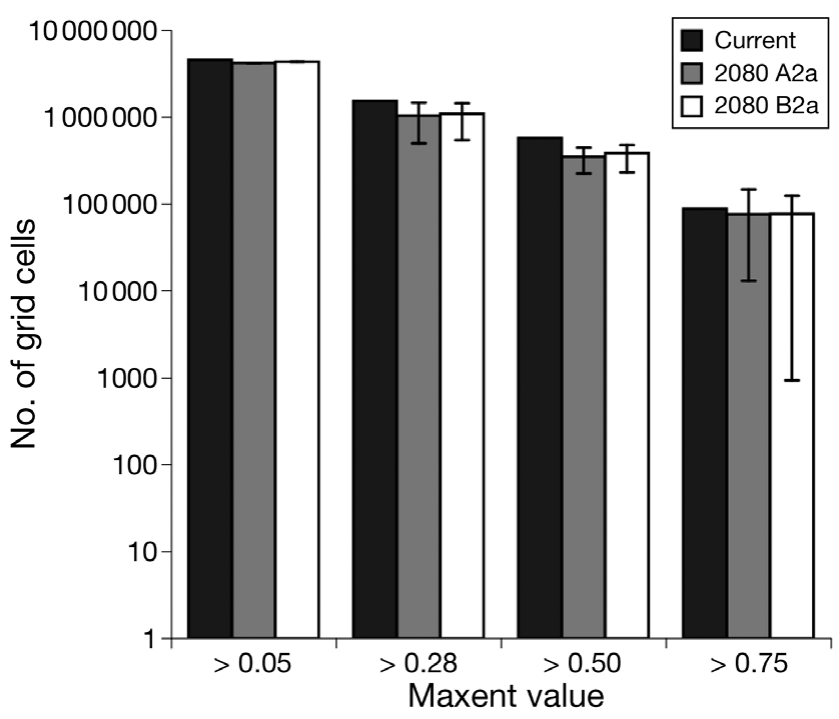

Fig. 2. Potential distribution area size of Batrachochytrium dendrobatidis $(B d)$ distribution in terms of number of $2.5 \mathrm{~min}$ grid cells and Maxent value classes derived from species distribution models under current climatic conditions and future anthropogenic climate change families A2a and B2a (Fig. 1). For A2a and B2a, the mean and range (error bars) are shown from projections onto the CCCMA, CSIRO and HADCM3 models

decrease or (3) geographically shift in (potential) distribution (Parmesan \& Yohe 2003, Parmesan 2006). All 3 responses occur in the conducted SDM for the future potential distribution of $B d$, with geographical range shift being predicted as the most common mode of change, i.e. towards higher latitudes and altitudes. Lafferty (2009) emphasized that, as all species, infectious diseases have upper and lower limits of their temperature tolerance. This may be expected to lead to shifts in their (potential) distributions if climate changes. The thermal limit of $B d$ is reached at $28^{\circ} \mathrm{C}$, where growth is inhibited, whereas prolonged periods above $30^{\circ} \mathrm{C}$ are lethal (Piotrowski et al. 2004). Furthermore, clinical studies have shown that transmission efficiency is likely to decrease with a rise in temperature, as this reduces both the fecundity per fungal sporangium and the period that zoospores are infectious (Woodhams et al. 2008). Currently, many tropical lowland areas in which $B d$ has been detected may at times reach temperatures at or above its thermal limit. The expected temperature increase will possibly render such regions unsuitable, e.g. by moving the temperature of colder microclimates above a critical threshold where $B d$ can persist. On the other hand, our SDM future projections indicate that the expected temperature increase may enhance $B d$ spread and successful establishment at higher altitudes in the tropics, especially in the Andes of South America. These results are consistent with observations in this region (e.g. Pounds et al. 2006, Seimon et al. 2007) and may also hold truth for others. SDM future projections also indicate that in temperate regions, $B d$ suitability, as a general trend compared to today, will decrease. However, especially in the Northern Hemisphere (e.g. northern North America and western Europe), this is contrasted by an increase in area highly suitable for the fungus (Fig. 1B,C). This does not compensate for the general area decrease, however (Fig. 2).

Even if climatic suitability for $B d$ decreases with anthropogenic future climate change, this does not mean per se that the risk for amphibian species to be affected by chytridiomycosis will respond correspondingly. This central question remains unstudied, as it is still unclear what exact mechanisms trigger clinical chytridiomycosis (Fisher et al. 2009). However, the development in the distribution of chytridiomycosis may very well have a trend parallel to that of the predicted optimal conditions for $B d$. Under the current climate, Rödder et al. (2009a) assessed the extinction risk for more than 3500 species of anuran amphibians by combining their expected susceptibility to $B d$ and $B d$ probability within species ranges. However, (potential) geographic ranges of most of these species under anthropogenic future climate change cannot currently be predicted. For successful model building, detailed information on species' natural history is pivotal (Rödder et al. 2009b,c), and such information is unavailable for the bulk of the global amphibian taxa. Only when knowledge on species-specific responses to particular climate variables is accessible (as for $B d$; Woodhams \& Alford 2005, Pounds et al. 2006, Rachowicz et al. 2006, Kriger et al. 2007, Lips et al. 2008, Rödder et al. 2008, Kielgast et al. 2009) can reliable future SDM projections be made (Rödder \& Lötters 2009, Rödder et al. 2009b).

Acknowledgements. We are grateful to J. Bielby, J. Bosch, M. Fisher, T. Garner, S. Schmidtlein, M. Veith and S. Walker for collaboration and fruitful discussion. Additionally, we thank A. Cunningham and anonymous reviewers for many helpful comments. D.R. thanks the Graduiertenförderung des Landes Nordrhein-Westfalen (Bonn University).

\section{LITERATURE CITED}

Alford RA, Bradfield KS, Richards SJ (2007) Ecology: global warming and amphibian losses. Nature 447:E3-E4

Andre SE, Parker J, Briggs CJ (2008) Effect of temperature on host response to Batrachochytrium dendrobatidis infection in the mountain yellow-legged frog (Rana muscosa). J Wildl Dis 44:716-720

Araújo MB, New M (2007) Ensemble forecasting of species distributions. Trends Ecol Evol 22:42-47

Araújo MB, Cabeza M, Thullier W, Hannah L, Williams PH (2004) Would climate change drive species out of reserves? An assessment of existing reserve-selection methods. Glob Change Biol 10:1618-1626 
Bielby J, Cooper N, Cunningham AA, Garner TWJ, Purvis A (2008) Predicting susceptibility to future declines in the world's frogs. Conserv Lett 1:82-90

Bosch J, Carrascal LM, Duran L, Walker S, Fisher MC (2007) Climate change and outbreaks of amphibian chytridiomycosis in a montane area of Central Spain; is there a link? Proc R Soc Lond B Biol Sci 274:253-260

Busby JR (1991) BIOCLIM: a bioclimatic analysis and prediction system. In: Margules CR, Austin MP (eds) Nature conservation: cost effective biological surveys and data analysis. CSIRO, Melbourne, p 64-68

Elith J, Graham CH, Anderson RP, Dudík M and others (2006) Novel methods improve prediction of species' distributions from occurrence data. Ecography 29:129-151

Fisher MC, Garner TWJ, Walker SF (2009) Global emergence of Batrachochytrium dendrobatidis and amphibian chytridiomycosis in space, time, and host. Annu Rev Microbiol 63:291-310

Flato GM, Boer GJ, Lee WG, McFarlane NA, Ramsden D, Reader MC, Weaver AJ (2000) The Canadian Centre for Climate Modelling and Analysis global coupled model and its climate. Clim Dyn 16:451-467

Gascon C, Collins JP, Moore RD, Church DR, McKay JE, Mendelson JR III (2007) Amphibian conservation action plan. IUCN, Conservation International, Gland, Cambridge

Gordon C, Cooper C, Senior CA, Banks HT and others (2000) The simulation of SST, sea ice extents and ocean heat transports in a version of the Hadley Centre coupled model without flux adjustments. Clim Dyn 16:147-168

> Hernandez PA, Graham CH, Master LL, Albert DL (2006) The effect of sample size and species characteristics on performance of different species distribution modeling methods. Ecography 29:773-785

Hijmans RJ, Cameron SE, Parra JL, Jones PG, Jarvis A (2005a) Very high resolution interpolated climate surfaces for global land areas. Int J Climatol 25:1965-1978

Hijmans RJ, Guarino L, Jarvis A, O'Brien R and others (2005b) DIVA-GIS version 5.2 Manual. www.diva-gis.org/documentation

IPCC (Intergovernmental Panel on Climate Change) (2000) Nakicenovic N, Swart R (eds) Special report on emissions scenarios. Cambridge University Press, Cambridge

Kielgast J, Rödder D, Veith M, Lötters S (2010) Widespread occurrence of the amphibian chytrid fungus in Kenya. Anim Conserv 13(Spec Iss 1):36-43

Kremen C, Cameron A, Moilanen A, Phillips SJ and others (2008) Aligning conservation priorities across taxa in Madagascar with high-resolution planning tools. Science 320:222-226

Kriger KM, Hero JM (2007) Large-scale seasonal variation in the prevalence and severity of chytridiomycosis. J Zool 271:352-359

Kriger KM, Peregolou F, Hero JM (2007) Latitudinal variation in the prevalence and intensity of chytrid (Batrachochytrium dendrobatidis) infection in eastern Australia. Conserv Biol 21:1280-1290

Lafferty KD (2009) The ecology of climate change and infectious diseases. Ecology 90:888-900

> Laurance WF (2008) Global warming and amphibian extinctions in eastern Australia. Austral Ecol 33:339-408

> Levine RS, Peterson AT, Yorita KL, Carroll D, Damon IK, Reynolds MG (2007) Ecological niche and geographic distribution of human monkeypox in Africa. PLoS ONE 2: e176, doi:10.1371/journal.pone.0000176

Lips KR, Diffendorfer J, Mendelson III Jr, Sears MW (2008) Riding the wave: reconciling the roles of disease and climate change in amphibian declines. PLoS Biol 6:e72, doi:10.1371/journal.pbio.0060072

Lötters S, Rödder D, Bielby J, Bosch J and others (2008) Meeting the challenge of conserving Madagascar's megadiverse ampibians: addition of a risk assessment for the chytrid fungus. Available at http://biology.plosjournals. org/perlserv/?request=read-response \&doi=10.1371/journal. pbio.0060118

Manel SP, Williams HC, Ormerod SJ (2001) Evaluating presence-absence models in ecology: the need to account for prevalence. J Appl Ecol 38:921-931

> Mendelson JR III, Lips KR, Gagliardo RW, Rabb GB and others (2006) Confronting amphibian declines and extinctions. Science 313:48

Nix H (1986) A biogeographic analysis of Australian elapid snakes. In: Longmore R (ed) Atlas of elapid snakes of Australia. Bureau of Flora and Fauna, Canberra, p 4-15

Parmesan C (2006) Ecological and evolutionary responses to recent climate change. Annu Rev Ecol Evol Syst 37:637-669

Parmesan C, Yohe G (2003) A globally coherent fingerprint of climate change impacts across natural systems. Nature 421:37-42

Phillips SJ (2008) Transferability, sample selection bias and background data in presence-only modelling: a response to Peterson et al. (2007). Ecography 31:272-278

Phillips SJ, Dudík M (2008) Modelling of species distributions with Maxent: new extensions and comprehensive evaluation. Ecography 31:161-175

> Phillips SJ, Anderson RP, Schapire RE (2006) Maximum entropy modeling of species geographic distributions. Ecol Model 190:231-259

> Piotrowski JS, Annis SL, Longcore JE (2004) Physiology of Batrachochytrium dendrobatidis, a chytrid pathogen of amphibians. Mycologia 96:9-15

Pounds JA, Coloma LA (2008) Beware the lone killer. Nature 2:57-59

Pounds JA, Bustamante MR, Coloma LA, Consuegra JA and others (2006) Widespread amphibian extinctions from epidemic disease driven by global warming. Nature 439: 161-167

> Pounds JA, Bustamante MR, Coloma LA, Consuegra JA and others (2007) Global warming and amphibian losses; the proximate cause of frog declines? (Reply) Nature 447: E5-E6

> Puschendorf R, Carnaval AC, VanDerWal J, Zumbado-Ulate H, Chaves G, Bolaños F, Alford RA (2009) Distribution models for the amphibian chytrid Batrachochytrium dendrobatidis in Costa Rica: proposing climatic refuges as a conservation tool. Divers Distrib 15:401-408

Rachowicz LJ, Knapp RA, Morgan JAT, Stice MJ, Vredenburg VT, Parker JM, Briggs CJ (2006) Emerging infectious disease as a proximate cause of amphibian mass mortality. Ecology 87:1671-1683

Rödder D, Lötters S (2009) Niche shift versus niche conservatism? Climatic characteristics of the native and invasive ranges of the Mediterranean house gecko (Hemidactylus turcicus). Glob Ecol Biogeogr 18:674-687

Rödder D, Veith M, Lötters S (2008) Environmental gradients explaining the prevalence and intensity of infection with the amphibian chytrid fungus: the host's perspective. Anim Conserv 11:513-517

Rödder D, Kielgast J, Bielby J, Schmidtlein S and others (2009a) Global amphibian extinction risk assessment for the panzootic chytrid fungus. Diversity 1:52-65

Rödder D, Schmidtlein S, Veith M, Lötters S (2009b) Alien invasive slider turtle in unpredicted habitat: a matter of niche shift or predictors studied? PLoS ONE 4:e7843, 
doi:10.1371/journal.pone.0007843

Rödder D, Kwet A, Lötters S (2009c) Translating natural history into geographic space: a macroecological perspective on the North American slider, Trachemys scripta (Reptilia, Cryptodira, Emydidae). J Nat Hist 43:2525-2536

Rohr JR, Raffel TR, Romansic JM, McCallum H, Hudson PJ (2008) Evaluating the links between climate, disease spread, and amphibian declines. Proc Natl Acad Sci USA 105:17436-17441

Ron SR (2005) Predicting the distribution of the amphibian pathogen Batrachytrium dendrobatidis in the New World. Biotropica 37:209-221

Seimon TA, Seimon A, Daszak P, Halloy SRP and others (2007) Upward range extension of Andean anurans and chytridiomycosis to extreme elevations in response to tropical deglaciation. Glob Change Biol 13:288-299

Skerratt LF, Berger L, Speare R, Cashins S and others (2007)

Editorial responsibility: Andrew Cunningham,

London, UK
Spread of chytridiomycosis has caused the rapid global decline and extinction of frogs. EcoHealth 4:125-134

Stuart S, Hoffmann M, Chanson J, Cox N, Berridge R, Ramani P, Young B (2008) Threatened amphibians of the world. Lynx Edicions, Barcelona

Swets JA (1988) Measuring the accuracy of diagnostic systems. Science 240:1285-1293

Wake DB, Vredenburg VT (2008) Are we in the midst of the sixth mass extinction? A review from the world of amphibians. Proc Natl Acad Sci USA 105:11466-11473

Woodhams DC, Alford RA (2005) Ecology of chytridiomycosis in rainforest stream frog assemblages of tropical Queensland. Conserv Biol 19:1449-1459

Woodhams DC, Alford RA, Briggs CJ, Johnson M, RollinsSmith LA (2008) Life-history trade-offs influence disease in changing climates: strategies of an amphibian pathogen. Ecology 89:1627-1639

Submitted: April 3, 2009; Accepted: January 11, 2010 Proofs received from author(s): March 31, 2010 